\title{
Globalization, Englishes, Global English, and Features of Nepalese English
}

\author{
Man Bahadur Jora \\ Lecturer of English \\ Kailali Multiple Campus, Dhangadhi, Kailali, Nepal
}

\begin{abstract}
This study tries to explore the features of Nepalese English. Along with the spread of globalization, there grew cultural flows and linguistic influences. Apart from globalization, global English, English and Englishes existed in the spreading of language territory. When they came into existence, the developing countries like Nepal got the impact of it. Consequently, Nepalese English is being used by people from Nepal although it is intended to be taught like native speakers. Behind this reason, English here is taught by non-native speakers and there is due influence of Nepali language. This paper reflects the experiences and uses of English by non-native teachers and students as well. Though Nepalese English is a variety of English, it has typical features that we can observe and realize among the Nepalese scenario. I interviewed the teachers and students to draw the features of Nepalese English. Finally, on the basis of their use of it at phonetic, syntactic, semantic and discourse level, I have talked about themes taken from the rigorous data analysis.
\end{abstract}

Keywords: globalization, global English, Nepalese English, features of Nepalese English

DOI: $10.7176 / \mathrm{IAGS} / 69-01$

\section{Introduction}

Currently there is very influential impact of globalization in each and every field. There is heavy influence of it in trade, language, culture, capital and labour market. The exchange of ideas, views, economic enhances, and rapid development cause worldwide circulation of things. A thing is not for certain place, but it is for the globe. In so doing, English is becoming global, there are different varieties of English have grown from the wing of globalization. There is not any typicality of culture, language, trade, marketing and capital. There is existed the hybridity and mixture of them. In the world, globalization is spreading in every sectors of the world. By linking with this, Nepal cannot be excluded from this in all areas including language. The objectives of this study are to explore Nepalese English as a different variety, and show features of Nepalese English. Likewise, Nepalese English has existed as a separate variety of English. It is prevailing in spoken and written discourse in Nepal and it is used differently. There are found distinct features of it.

\section{Globalization}

The term Globalization has emerged in the present world rapidly. It is synonymous to westernization. It refers to world commerce etymologically. It is a process of being connected through phone, face book, road, rail links, and planes; banks and industries etc. It is the process of globalizing. It is the process of interaction and integration between people, companies, and governments worldwide. Globalization has grown due to advances in transportation and communication technology and it is the byproduct of migration (Fairclough, 1992; 2010). It is a flow of people, goods and thus capital. With increased global interactions, there is growth of international trade, ideas, and culture into the wave of globalization. It is primarily an economic process of interaction and integration that's associated with social and cultural aspects.

Different people define it differently. Steger (2003) states that globalization is a social process characterized by the existence of global economic, political, cultural, linguistic and environmental interconnections and flows that make the many of the currently existing borders and boundaries irrelevant. Globalization is not as recent a phenomenon as economists have generally led us to believe, although it has undoubtedly operated in faster and more complex ways since the late 1980s. To quote Webster (2015), globalization is the act or process of globalizing the state of being globalized, especially the development of increasingly integrated global economy marked especially by free trade, free flow of capital, and the tapping of cheaper foreign labor markets. According to Business Dictionary, Globalization is the worldwide movement toward economic, financial, trade, and communication integration. Thus, globalization is a process of international integration evolving from the interchange of world views, products, ideas, and other aspects of culture which overpowers networking in every field.

\section{Emergence of Englishes}

Different Englishes emerged in the world with the spread of English. There is the circle of English speaking countries. Kachru (1985) classifies into them concentric circles as inner, expanding and outer. In terms of meaning of World Englishes, Bolton (2008) presents several interpretations such as an umbrella term covering 
all varies of Englishes, new Englishes in countries such as Africa and Asia. However, the term World Englishes will be used, as Jenkins (2006) proposed, to cover new Englishes in Africa and Asia, which are considered as Outer Circle by Kacru. Wardhaugh (1986) asserts, "when we look closely at any language, we will discover time and time again that there is considerable internal variation and that speakers make constant use of many different possibility offered to them" (p. 5). Labov (1972) observes that "it is common for a language to have man' alternate ways of saying "the same" thing" (p. 188). Similarly, he argues that internal structure pressures and the sociolinguistic pressures act in systematic alternation in the mechanism of linguistic change. In the same vein, the scholarly discussion on World Englishes in applied linguistics moves towards multiple varieties of English as legitimate and worthy study (Matsuda, 2003).

Graddol (2005) says that new varieties of English - often referred to as New Englishes quickly emerged from contact with local languages. Indeed, by the end of the nineteenth century, there was concern that these New Englishes were diverging so much from native-speaker varieties that English would become a group of mutually unintelligible languages, in the same way as Spanish, French and Italian evolved from Latin. World English might have been no more than a celebration of diversity, like World Music, rather than the global lingua franca which it has also become. There are some reasons behind it. First, there is a principle of mutual intelligibility. It turns out that native-speaker varieties (including both American and British) are not actually as intelligible as some second language varieties worldwide. Furthermore, strict adherence to a particular standard of usage may not be the most important means of achieving mutual comprehension. Thus, different varieties of English came into existence. Nepalese English is one of the varieties of English growing rapidly like Jenglish, Chinglish, Henglish and so forth.

In preparing their academic discipline to get ready to face the globalized world, the practitioners of Applied Linguistics bear a special responsibility because they largely deal with a language that has both global and colonial characteristics. "A language achieves a genuinely global status," observes Crystal (1997, p. 2), "when it develops a special role that is recognized in every country." Clearly, English has achieved such a role. It has become the world's lingua franca. Because of its association with global economy, it is taken as the natural choice for progress and prosperity. It is seen as opening doors for social mobility within and across national borders. With globalization, English is in the corollary of being worldwide. It is spoken and written differently in accordance with the ease and understanding of the users. People are using it for completing their hand to mouth and as a means of communication. Consequently, there have emerged different types of English. They are set as the varieties of it in the arena of globalization.

\section{Global English}

The English language is the language of many people in the globe. Because of this quality, it has become a global language. Native speakers use Standard English every day. Global English is just opposite of Standard English. In the words of Norvet (2016), global English modifies the rules of Standard English to eliminate the confusion of Standard English. He argues that global English is used to make English writing as unambiguous as possible. Global English is easier and it consists of short and easy sentences. It advocates day to day English. Metaphors or figurative language is not used. The content is literal and logical. It is the factory of globalization.

As Graddol (2005) concedes, the development of English as a global language is one of the most remarkable phenomena of the late 20th and early 21 st centuries. In the same way, he states that for the first time in the history of human society, a single language has become sufficiently universal that it can be used as a global lingua franca for communication between speakers of many languages. He pinpoints that the history of English has traditionally been divided into three main phases: Old English (450-1100 AD), Middle English (1100-circa 1600 AD) and Modern English (since 1600). But it seems that Global English represents a new and fourth phase in which its main use around the world is between or among non-native speakers has only just begun and in which both the status and linguistic form of the language are rapidly developing. The majority of the world's population can speak English.

\section{Nepalese English}

Nepalese English is a variety of English. In Nepal, it is spoken and written with the influence of Nepali language. The concern of this paper is to find out the Nepalese English's features. To quote Sharma, Joshi and Teijlingen (2015), the English spoken by native-Nepali speakers (Nepenglish) is a separately developing variant of English. They argue that Nepali English bears such a similarity with Indian English, as both are largely based on originally Sanskrit-based languages. Karn (2011) says that English as a divergent variety has grown in Nepal with its own distinctive features at all levels of language. The emergence and growth of new English in Nepal, however, have generated heated debates amongst scholars. From these views, it can be said that Nenglish or Nepalese English is developing in Nepal.

Similarly, internal structure pressures and the sociolinguistic pressures act in systematic alternation in the mechanism of linguistic change. Therefore variety of language is born from social situations, needs and 
comprehensibility of users and the influence of mother tongue. There is influence of language after colonialism. When countries become free, people try to develop and use the language for their ease. Similarly, in the words of Seidlhofer (2001, p. 135, as cited in Bhatt, 2010) people use English as freely as their own language. Furthermore, he adds that indeed post - colonial Englishes have shifted the focus on identity, from parochial domesticity and exclusive colonial norms to global inclusiveness and egalitarian license to speak, and their users write in ways that meet diverse local needs. English in Nepal is flowering in the mode of establishing as its own features. That is why I took this study as heart of finding the situation of Nepalese English.

\section{Method}

I consulted different sources to bring my study in this configuration. Mainly, I build on idea from the voice theory of Mikhail Bakhtin. People have their own styles speaking which make their languages different from others. In terms of this, Robinson (2011) forwards his view that in Problems of Dostoevsky's Poetics (1929), Bakhtin developed the concepts which were to inform much of his work. He talks about a diversity of individual speeches. I selected this theory is to show differences in English language of people from Nepal having its own salient features. I also wanted to link my study with linguistic diversity. In so doing, I studied Hockett's (1960) 'The Origin of Speech'. He argues that human language may be defined as a human-learnable communication system with conventionalized form-meaning pairs capable of expressing the entire communicative needs of a human society. Regarding my study, I developed an idea in my mind that Nepalese English also is not like native speakers' one, but it grows as the non-native features of Nenglish.

I used the primary and secondary sources of data. I went through the secondary sources like the works of Bolton (2008), Fairclough (1992, 2010), Kachru (1985), Kumaravadavelu (2008), Business Dictionary, Robinson (2011), Steger (2003), Labov (1972), Webster (2015), Graddol (2005), Wardhaugh (1986), and other important relevant sources. In the case of this study, I went to the field as the case of collecting primary sources of data. My study is based on spoken discourse of Nepalese English. For the study, I selected two English teachers teaching English at secondary level and two students studying at different levels. I also observed the classes of English. They were two teachers from Kailali, two students studying at Kailali Multiple Campus, and two my colleagues from M. Phil. Level from GSE, Kirtipur. I have used pseudo names for them. I took their deep interview and I also observed the class for collecting data. I recorded their voices on my cell phone and also made notes on my diary.

After collecting data, I applied the purposive sampling method to analyze the data which I recorded and collected through the deep interview. Then I analyzed it rigorously. Moreover, I collected the data from the informants to study the Nepalese English from the angle of spoken discourse. This is the age of globalization and there is flow of it in language and culture. I have analysed pronunciation style, tag questions, code mixing, use of discourse markers, sentence composition and style of using plural markers appear in it. I found their English language different which revealed feature of Nepalese English.

\section{Results and Discussion}

I explored the characteristics of Nepalese English on the basis of existing features of it. The interlocutors of English speakers from Nepal try to reveal different sorts of features of it. In spoken and written discourse, the Nepalese English is prevalent. But, for my concern, I tried to study spoken discourse. I tried to explore it in phonetic, syntactic, semantic and discourse level. As I said earlier part, I selected 4 persons for the elicitation of data and I observed two classes at M. Phil. level students. I mean to say here is that I found Nepalese English features on the basis of it. After the establishment of Durbar High School, there commenced the formal teaching learning of English (Shrestha, 2008). Then it did not confine in teaching learning, but it spread to different areas. The following section can reveal and justify how and why Nepalese English is distinct variety.

\section{Phonetic Features of Nepalese English}

Phonetic features are related to pronunciation. Adhikari (2005) views that Nepalese English is typical because it is pronounced in the Nepalese English form. Mostly, English pronunciation done here includes some additional characters. The insertion of vowel /i/ sound before $s p$, st and $s k$ clusters was the common practice among the Nepali speakers. For example, When I asked to say these words to students I selected, they pronounced school as /isku:1/ for, star as /istar/, and speak as /ispik/. In RP, they are pronounced as /skül/, /star/ and /spik/. Similarly, I told them to pronounce formula. The another variation that I got noticed in Nepali English was the use of /a:/ sound at the world final position which in RP doesn't occur in world final position instead /a/ usually occurs and pronounced. When I went through the recorded text done at the time of data collection, I found that the word 'formula' was pronounced as /fərmula/ instead of /fo:mjula/.

Moreover, the long vowel /a:/ was uttered as /a/- the short one because in Nepali only single /a/ sound exists and the length of the sound doesn't bring any changes in its meanings. In the process of data collection what I recorded as pronounced by Santosh was: 
I went to ischool yesterday. Then I uttered istar as my teacher instructed. After that he engaged us in pronouncing the words like ispeak, istation, istaff and other words. I have a isma:l story.

When I listened the pronunciation of Prakash whatever he was speaking. Similarly, I found his speaking as others pronounced by non-native English teacher was: /the formula was iziar/, and / I helped archana/. He again said I got in the school at my ismal age to refer to /smol/ as /isma:1/. The native speakers do not produce the sound /a/ word finally, but they pronounce as /a/. In the respect of Nepalese English speakers, they did not pronounce as /a/. I found that Nepalese speakers of English did not pronounce like that. So, it can be said that the Nepali speakers don't notice whether the sound should be long or short. They pronounce on the basis of the nature of syllable timed Nepali language. It happened because there are no such word initial clusters in Nepali language and due to the influence of their mother tongue they inserted /I/ sound to make them easy to produce the utterances and pronounced /a/ instead of /a/. There are many other case cases where we can find Nepalese pronunciation. The sound $/ \mathrm{r} /$ is is pronounced word everywhere. The other case is that the sound $/ \mathrm{gh} / \mathrm{which}$ is not found in English is pronounced in Nepalese English, for example /ghana/ and /ghost/.

\section{Discourse Markers in Nepalese English}

It is another important feature of Nepalese English. There is influence of discourse markers from in accordance of users. They apply the discourse markers in their own way. They use them from their own language. Even some speakers try to speak English, but again there is mixture of Nepali discourse markers in the flow of speaking. Likewise I observed the class of M. Phil. level students at the time of presentation. In this respect, Bimal was giving the class and uttering the discourse maker 'ok' most of the time he was speaking. He taught as semantics as the related aspect of meaning, ok. It goes towards the meaning level, ok. Furthermore, he said the pragmatic meaning deals with the speaker's meaning, and it provides the contextual meaning, ok. Ok, then it is connected to the situational aspect, ok.

I also observed the class of Hark at M. Phil Level. He took the class, and most of the time he was saying the discourse marker 'No'. In the process he said tense and time go together, No. For tense only the use of verb is not significant, 'No'. There are indexicals in the formation of sentences. We use them to refer to time indexicals, 'No'. From these, it can be said they use discourse markers in many cases as there is pertaining the use of discourse markers from Nepali language. The use of discourse markers is applied in the form of repetitive way while speaking English language. They say the discourse markers like ok, right, you know, oh, and no frequently. Sometimes the Nepalese English speakers use the discourse markers form their own language like matlab, chahinejo, bilkul and so forth.

\section{Use of Tag Questions}

In English, tag questions are used for confirmation. The tags in English have their own rules for using. Bhatt (2005) argues that tags express certain attitudes of the speaker toward what is being said in the main clause and in terms of speech acts and/or performatives. Functionally, tags in English generally behave like epistemic adverbials such as probably and presumably. There is case of positive and negative aspect and the concern of tense has to be considered in English. Nepali users of English do not take care of such questions and their uses. The tag questions made by them are found used in their own way. In this context, I took the deep interview with Keshav. He used the tag questions from Nepalese angle in the following way.

I did not go there, is it?

She never helped me, is she?

Go there, is it?

This vignette depicts that Nepalese English don't have the following the rules of changing into tags correctly. The vignette makes us clear that there is cultural influence in using language. In other words, such tags serve positive politeness functions (Brown and Levinson, 1987), signaling deference and acquiescence. They say whatever they like to say. I made query that why they used such constructions of tags. They answered that all the time it is not better to follow rules and who knows rules always. They again added that language means communication. If there is communication, that is correct use of language.

\section{Use of Conditionals in Nepalese English}

Conditionals in English run in accordance with the rules. They are used for expressing conditionals or hypotheses. There is consideration of tenses while changing or completing them. During my study, I observed class of teachers teaching the conditionals. Sometimes they used correctly. In the class taken by Hari sir, different students answered as follows:

Student A: If they helped me, they will be told good persons.

Student B: If you had come here, I would be please.

Student C: If they come here, they will get something.

From these exponents, it can be justified that conditionals in Nepalese English again in the sense of 
their Nepali language. These conditionals include Nepalese style of saying. They used conditionals in accordance with the tense aspect in their language. The conditionals in the present the future meaning, past tense reflects the present meaning and the past perfect signifies the past meaning. But, it is not considered in Nepalese English because they look at structure but not the context. Again, in Nepali language there exists the meaning of their regarding tense. Therefore, they use such structures.

\section{Code Mixing}

While speaking English in Nepalese context, the users use the words from their language. Sometimes there is use of code switching. In the usage of utterances, they say words from Nepali language which does not occur in English. I went to Hari sir for asking the things in English. The verbatim he uttered is as following:

I like say something, beta. I had a chhoro who don't like to study as you do. I am in danger condition when I think about my jiban sathi. I have a problem of giving advice, beta. I say feri that I had a trouble of my family. My old aama becomes sad when she thinks about the problem of my family.

This verbatim signifies that Nepalese English does not exclude some words from their own language to emphasize and again they use code switching due to the flow of globalization. The words used here beta, chhoro, jiban sathi, and aama are the examples of that flow. On the other hand, they denote the usage of code switching. That is why this is another feature of Nepalese English. Then I went to Prakash sir to study about Nepalese English. I asked him to describe about present time people in English. He started as following:

Today's people are very pakhandi. They make jatra of their body parts. They do not become shy about their secret body parts. The boys scold each other by using language about the secret body parts. The girls are walking by making the mohatsab of their chest. The boys use fucking language. They have no khubility.

This verbatim is another feature of Nepalese English. In this verbatim, the word pakhandi, jatra, mohatsab and khubility are examples of self-creation. They show the typicality of Nepalese English. Similarly, the words used here-i.e. secret body parts are related to sexual organs. They are tried to be used as taboo like and said in culturally digested way. The words are said in accordance with cultural boundaries.

\section{The Borrowing of Cultural Words and Concepts}

Culture is an integral part of the people and the society. People do not become ready to translate their cultural terms easily and directly. Some words from Nepalese culture are untranslatable. They do not have equivalent terms in English. They are not available in the English language. In such case, they borrow the words from their own language. Linking with this, Prakriti said as:

I fasted at Ekadashi. I went to pandit to listen the religious matters on the day.

We wear janai because we are Hindus. My friend gave me one mana of rice.

My young brother will have bratbandha tomorrow.

These exponents highlight the flavor of cultural words. English culture does not have these terms. So, they are saved and borrowed in the Nepalese English. The words like ekadashi, pandit, janai, mana and bratbandh are cultural words. Using them in the same way is another feature of Nepalese English. Translation is not preferred for communication. Moreover, these words have their own value when said in the English whatever they are. Therefore, Nepalese English is a divergent variety of English.

\section{Use of Plural Markers}

Plural markers are used for transforming singular numbers in plural ones. In English, they are possible when nouns are changed into plural ones. In the respect of uncountable nouns and abstract concepts, they are not possible. The plural markers in it are -s, -es, and -ies. In English, the plural markers sometimes are seen within the words as men, oxen, geese, etc. In Nepalese English, they are practiced in a self-way. In collecting data, I elicited from Keshav the use of plural markers as:

Boy-boys, girl-girls, woman-womans, man-mans, democracy-democracies, sugar-sugars, incompleteness-incompletenesses, etc.

These transformative forms show that the plural markers are used in their own way in Nepalese English. They use them without taking care in numbers and noun forms. The non-native speakers change the uncountable and irregular forms according to the rules whatever they use in changing the singular ones. They do not make any differences while changing from singular to plural forms. Even the uncountable forms are changed into plural forms in Nepalese English which are not possible in native English. They argue that plural forms are also possible for uncountable nouns and abstract forms. Thus, this is another feature of Nepalese English applied by the speakers.

\section{Conclusion}

With the flow of globalization, English became the language of communication. Kumaravadivelu (2008) says 
that English became the industry of globalization. Consequently, in the present time, English is a global language and it is used differently in different countries. Canadian English, Scottish English, Indian English, Japanese English, etc. are some examples of Englishes. Nepalese English is one of them which has its own features. English is not just spoken and used as the native speakers, but it comes into the tongue of Nepalese speakers from their own way. Nepalese English has established as a divergent variety having its own ways of pronunciation, using tag questions, making conditional uses and using the tenses. They borrow the cultural terms from their own language.

According to Kachru (1985), English has been indigenized in India as well as other countries including Singapore, Nigeria, which are referred to outer circles. He has mentioned it in terms of concentric spheres of English. With the wheel of spreading English in the global continuum, varieties of English existed, have existed and are in the process of existing along with the ease of the users, influence of their mother tongue languages and their social and cultural etiquettes. The present study attempts to show Nepalese English as a separate variety having its distinctive features.

\section{Acknowledgements}

I would acknowledge Prof. Dr. Bal Mukunda Bhandari for his intense care, consistent guidance and encouraging ideas to do the research work, and bring this paper into this form. I would like to thank my respected guru Prof. Dr Jai Raj Awasthi, who provided me ample sources of materials and flows of encouragement. Similarly, I have to express my gratitude to the authors, thinkers and linguists whose contributions became milestones for my research work. I am also indebted all the informants who helped me to elicit the findings from their data provided cordially. Finally, special thanks go to all my mates who supported me directly and indirectly in the configuration of this work.

\section{References}

Adhikari, M. (2017). English in Nepal: Phonology of Nepali English? NELTA ELT FORUM. Retrieved from https: // neltaforum.wordpress.com

Bhatt, R. (2010). Unraveling post - colonial identity through language .In Coupland, N. (Ed.) (2010). The hand book of language and globalization. Oxford, USA: Wiley-Black-Well

Baldwin, T. \& Lui, M. (2010). Human language technologies: The 2010 annual conference of the North American the chapter of the ACL. Los Angeles, California .Association for computational linguistics. 229237. Retrieved from http://dev.opera.com/articles/view/

Bolton, K. 2008. English in Asia, Asian Englishes, and the Issue of Proficiency. English Today, 24 (2), 3-12.

Brown, P. \& Levinson, S. C. (1987). Politeness: Some universals in language usage. Cambridge: Cambridge University Press.

Business Dictionary. Definition. Globalization. Retrieved from: http://www.business.com /definition/globalization.html

Fairclough, N. (1992). Discourse and social change. Cambridge: Polity Press.

Fairclough, N. (2010). Critical discourse analysis ( $2^{\text {nd }}$ ed.). New york: Pearson Education Limited.

Graddol, D. (2005). Spoken everywhere but at what cost? The Guardian. [Online]. Retrieved from https://www.theguardian.com/theguardian/2005/apr/20/guardianweekly.

Hockett, C. D. (1960). The origin of speech. Scientific American, 203(3), 88-96. http://dx.doi.org/10.1038/ scientificamerican 0960

Kachru, B. B.(1985). Standards, codification and sociolinguistic realism: the English language in the outer circle. In: Quirk, R \& Widdowson, H.G. (Eds.). (1985). English in the World: teaching and learning the language and literatures (pp. 11-30). Cambridge: Cambridge University Press for The British Council.

Kumaravadivelu, B. (2008). Cultural globalization and language education. New Haven, CT: Yale University Press.

Labov, W. (1972). Language in the inner city: Studies in the Black English vernacular. Philadelphia: University of Pennsylvania Press.

Robinson, W. I. (2011). Globalization and the sociology of Immanuel Wallerstein: A critical appraisal. International Sociology, 26(6), 723-745. doi: 10.1177/0268580910393372

Sharma, S., Joshi, P., \& Teijlingen, E. V. (2015). Nepenglish or Nepali English: A new version of English? Asian Journal of Social Sciences \& Humanities, 4(2). Retrieved from http://www.ajssh.leena-luna.co.jp/

Steger, M. F. (2003). Globalization: A Very Short Introduction. Oxford: Oxford University Press.

Wardhaugh, R. (1986). An introduction to sociolinguistics. New York: Basil Blackwell.

Webster, M. (2015). Dictionary. Globalization. Retrieved from https:/www.merriam.webster.com/ 